\title{
One-shot Image Style Transfer via Pre-trained GAN Inversion
}

Zegang Wang ${ }^{1}$

${ }^{1}$ Affiliation not available

February 5, 2022

\section{Hosted file}

2021_Arxiv.pdf available at https://authorea.com/users/458824/articles/555286-one-shotimage-style-transfer-via-pre-trained-gan-inversion 